\title{
O LIVRE CONVENCIMENTO COMO FUNDAMENTAÇÃO DA DECISÃO JUDICIAL PÓS CPC/15: A FILOSOFIA DA CONSCIÊNCIẢ AINDA PERMEIA O PODER JUDICIÁRIO?
}

\author{
Cristiano Becker Isaia* \\ Bruna Andrade Obaldia**
}

RESUMO: O trabalho pretende investigar a relação entre filosofia da consciência e decisões judiciais proferidas na vigência do CPC/15. Inicia-se pela compreensão do paradigma da filosofia da consciência e seu deságue à subjetividade do julgador, porquanto necessário à verificação de sua incidência nas decisões abordadas. Ato contínuo, o estudo trata do livre convencimento judicial, seguido de jurisprudência atual que guarda relação com o tema. Ao final, a pesquisa permitiu compreender que a alegação do livre convencimento do juiz a fim de fundamentar a decisão judicial é (uma das) face(s) que comprova a presença da filosofia da consciência no ambiente processual.

PALAVRAS-CHAVE: Decisão. Filosofia da Consciência. Julgador. Livre Convencimento. Subjetividade.

\section{THE FREE CONVINCING AS SUBSTANTIATION FOR THE JUDICIAL DECISION AFTER CPC/15: THE PHILOSOPHY OF CONSCIOUSNESS STILL PERMEATES THE JUDICIAL POWER?}

\begin{abstract}
The work pretends to investigate the relation between philosophy of consciousness and judicial decisions issued under the $\mathrm{CPC} / 15$. It begins with an understanding of the philosophy of consciousness paradigm and its displacement to the subjectivity of the judge, as necessary to verify its impact on the decisions approached. Immediately, the study deals the free conviction of the judge, followed by current jurisprudence that is related to the topic. In the end, the research allowed to understand that the allegation of the judge's free conviction in order to substantiate the judicial decision is (one of) the face(s) that proves the presence of the philosophy of consciousness in the procedural environment.
\end{abstract}

KEYWORDS: Decision. Judge. Free Convincing. Philosophy of Consciousness. Subjectivity.

\section{INTRODUÇÃO}

\footnotetext{
Doutor e Pós-Doutor em Direito pela Universidade do Vale do Rio dos Sinos (UNISINOS). Professor do Programa de Pós-Graduação em Direito da Universidade Federal de Santa Maria (PPGD/UFSM). Coordenador do Núcleo de Estudos Avançados em Processo Civil (NEAPRO) da UFSM. Endereço eletrônico: cbisaia@ gmail.com

Mestranda em Direito pelo PPGD/UFSM. Membro do NEAPRO/UFSM. Bolsista CAPES. Endereço eletrônico: obaldiabruna@gmail.com
} 
O direito não é uma ciência estanque. Por (precisar) acompanhar as transformações experimentadas pela sociedade da qual faz parte ao longo do tempo, seja no que diz respeito à estrutura cultural, econômica, política e/ou social, é que pode ser depreendido seu cariz mutável. Tal situação acontece (ou, ao menos, deveria acontecer) em todas esferas que compõem o ordenamento jurídico pátrio, seja ele de ordem material ou processual, sempre que suas disposições normativas desafinarem em relação às necessidades dos casos apresentados em um mesmo lapso de temporalidade.

O Código de Processo Civil (CPC), por seu turno, é um dos exemplos da situação exposta. O diploma anterior vigeu a partir do ano de 1973 (Lei $\mathrm{n}^{\circ}$ 5.869/1973) e estruturou a jurisdição processual civil no país por mais de quatro décadas. Após tal decurso de tempo, passou a viger em março de 2016 o Código de Processo Civil de 2015 (Lei n 13.105/2015). O novo CPC, ainda em seu projeto, conteve muitas propostas para reinventar o processo civil. Ideias de instituição de incidentes, alteração de ritos procedimentais e a supressão de recursos e práticas presentes no então vigente $\mathrm{CPC} / 73$ que, sob o ponto de vista dos proponentes, eram incompatíveis com o cenário jurídico atual.

Após o texto final ser sancionado, o CPC/15 trouxe consideráveis alterações em relação ao Código antecedente. Uma das mudanças mais expressivas, ao menos sob um olhar hermenêutico, foi a supressão da previsão do livre convencimento motivado do julgador no momento da fundamentação das decisões judiciais. Anteriormente previsto no art. 131 do $\mathrm{CPC} / 73$, o livre convencimento do juiz não encontrou morada na nova legislação. $\mathrm{O}$ seu artigo correspondente no CPC/15 é o art. 371, que se ocupa apenas em determinar a apreciação das provas e a obrigatoriedade de fundamentação das decisões, silenciando sobre a possibilidade de justificar o ato de julgar com base no convencimento livre do julgador.

Dirigindo uma compreensão hermenêutica à mudança, é possível depreender o seu escopo: eliminar ou, ao menos, restringir as margens para a incidência da discricionariedade judicial nas decisões. Assim, o teor do art. 371 pode ser considerado uma conquista hermeneuta impulsionada pela invasão da linguagem na filosofia do e no processo e o consequente afastamento do paradigma da filosofia da consciência que sustenta(va) a subjetividade.

Ocorre que atualmente, passados mais de quatro anos do início da vigência do CPC/15 no ordenamento pátrio, ainda é possível verificar decisões judiciais fundamentadas no livre convencimento motivado dos julgadores, em flagrante apego às ideias de um 
dispositivo legal que não mais vige e às próprias matrizes da filosofia da consciência. Nessa toada, a pesquisa busca discutir em que medida o paradigma da filosofia da consciência (ainda) permeia as decisões judiciais e qual a relação estabelecida entre a (tentativa de) fundamentação judicial pelo livre convencimento do juiz com o já mencionado paradigma.

Assim, a pesquisa objetiva, sob uma perspectiva geral, investigar a atual relação estabelecida entre a filosofia da consciência e as decisões judiciais proferidas na vigência do CPC/15. Destarte, o trabalho gira em torno da compreensão do instituto (intitulado, por alguns, como princípio) do livre convencimento do magistrado como elemento válido para constituir a fundamentação das decisões judiciais e seu vínculo com o paradigma da subjetividade. Para que isso seja possível, o estudo foi, para fins didáticos, concentrado em dois objetivos específicos, responsáveis pela subdivisão do conteúdo a ser trabalhado em duas seções que doravante serão esmiuçadas.

Tendo em vista a delimitação da pesquisa, a título de objetivos específicos, o trabalho inicia pela compreensão acerca da matriz estrutural do paradigma da filosofia da consciência e seu inevitável deságue à subjetividade do julgador no que tange à tomada de decisões em direito, porquanto necessário à verificação de sua incidência nas decisões abordadas. Em posse disso é que o estudo procura investigar, ainda na primeira seção, a subjetividade, como fruto da filosofia da consciência, e seu inevitável deságue nas decisões judiciais, que foi arraigada no terreno das decisões judiciais e sua interligação com o instituto do livre convencimento do juiz.

Ato contínuo, de modo a complementar e aprofundar a temática da primeira seção, o estudo trata do instituto do livre convencimento do juiz, seguido de jurisprudência atual que guarda relação com o tema, a fim de que possa ser auferida a incidência ou não da filosofia da /consciência nas decisões judiciais. Por isso, debruça-se sobre o art. 371 do CPC/15 a fim de investigar a sua inovação textual (em comparação ao dispositivo análogo do CPC/73, no art. 131), que suprime a previsão expressa da possibilidade da fundamentação judicial invocar o livre convencimento do magistrado. Sob tal perspectiva, a segunda parte do estudo também se ocupa em investigar de que maneira restam as (tentativas de) fundamentação das decisões judiciais com fulcro no livre convencimento do julgador em face da realidade jurisdicional inserida em um contexto de CPC/15.

Com o intuito de, por meio dos objetivos específicos, solucionar os problemas de pesquisa anteriormente explicitados, o presente trabalho buscou determinar suas escolhas 
metodológicas com vista à necessidade de conhecimento dos objetos que ora delimitam o estudo. Sob tal perspectiva é que pretende utilizar a abordagem fenomenológicohermenêutica, como negação do método. Isso porque a pesquisa gira em torno de uma compreensão hermenêutica acerca das decisões judiciais no direito processual civil e, consequentemente, diverge dos ideais metafísicos que permeiam a (tentativa de) matematização e verdades absolutas propostas em métodos.

O método de procedimento escolhido, por sua vez, é o monográfico. A escolha pode ser justificada pelo fato de que o estudo visa compreender o instituto do livre convencimento do juiz e o paradigma filosófico da subjetividade que o sustenta, de maneira determinada, a fim de que, ao longo da pesquisa, as respostas obtidas a fim de solucionar o problema de pesquisa elaborado consistam em generalizações obtidas acerca dos elementos que compõem os objetivos específicos do trabalho.

Ademais, a técnica de pesquisa a ser trabalhada é a bibliográfica, tendo em vista a pretensão de investigar material teórico como artigos científicos, livros e teses, e também jurisprudencial, no âmbito do Supremo Tribunal Justiça, com a finalidade de responder às indagações postas ao desenvolver do ensaio. No que tange à teoria de base, que tem por escopo alicerçar a edificação de todo o desenvolver do trabalho ora proposto, é adotada a Crítica Hermenêutica do Direito (CHD) angariada pelo jurista gaúcho Lenio Luiz Streck.

Ressalta-se, ainda, que a justificativa da presente pesquisa gira em torno da necessidade de compreender a relação estabelecida entre os paradigmas filosóficos e a constituição dos institutos que compõe a jurisdição processual, principalmente quando esses laços são responsáveis por práticas que afrontam direitos constitucionalmente consagrados, como é o caso da fundamentação das decisões judiciais a todos que buscam o judiciário.

\section{DECIDO ASSIM PORQUE PENSO ASSIM: A SUBJETIVIDADE DA FILOSOFIA DA CONSCIÊNCIA ARRAIGADA NO TERRENO DAS DECISÕES JUDICIAIS E SUA INTERLIGAÇÃO COM O INSTITUTO DO LIVRE CONVENCIMENTO}

Seguindo a referência introdutória de que o direito é uma ciência de caráter altamente mutável, que assume uma capacidade de ser (re)modelável em virtude da temporalidade em que está inserido, há que se pensar em quais são os pontos de reflexo dessa necessidade de enfrentar e acompanhar as constantes mudanças experimentadas pela realidade que está 
inserto ao longo do tempo. Sob tal ótica, convém que a investigação seja concentrada no âmbito do direito processual, mormente o civil, por ser o fator delimitador e, por isso, escopo central da presente pesquisa.

No que tange às metamorfoses experimentadas pela ciência do direito processual ao longo da história, em face da perspectiva proposta por Streck (2014, p. 38), “é razoável afirmar que o direito, enquanto legado da modernidade - até porque temos uma Constituição democrática - deve ser visto, hoje, como um campo necessário de luta para implantação das promessas modernas." Tal necessidade ganha destaque em países inseridos em um contexto de modernidade tardia - e em face de um Estado Democrático de Direito -, como é o caso do Brasil.

A jurisdição processual, que inegavelmente avança a cada conquista democrática atingida, também enfrenta dificuldades estruturais que estão arraigadas no ambiente do processo há muito tempo. São problemas crônicos que, embora com o esforço sólido de muitos agentes para afastá-los, ainda persistem. Dentre eles, encontra-se o paradigma da filosofia da consciência. Anunciada ante a expectativa de rompimento com o paradigma da objetividade que, ancorado em uma metafísica clássica, demonstrava, à época, sinais de desgaste teórico estrutural, a filosofia da consciência buscou evoluir estruturalmente no que diz respeito à relação estabelecida entre sujeito e objeto.

Junto à insuficiência do paradigma da objetividade (ou paradigma aristotélicotomista) - fruto do ideal do objetivismo científico que almejava, sobretudo, tratar a todos os fenômenos como dados -, o que muito colaborou para o nascimento da subjetividade foi o movimento do Iluminismo. Modificador essencial das e nas searas política, social e cultural, o período iluminista pode ser caracterizado como um recorte histórico importante da humanidade. Nele, o homem restou elevado à posição de sujeito central de todo o saber científico e, ato contínuo, racional. A razão humana é sobrelevada de forma que passa a ser considerada a morada de todo o conhecimento.

Tal visão antropocêntrica, de viés racional, corroborou para que a maneira como a sociedade enxergasse as atividades desenvolvidas pelo homem mudasse. Dentre essas atividades, estava inserida a jurisdicional: surge, então, a invasão da ideia de que a subjetividade do julgador deveria influir diretamente nas decisões judiciais, já que era reflexo da sua razão. Em uma época de supervalorização da figura do homem e, pois, de sua razão, 
sujeitar a resolução dos conflitos à consciência do juiz, enquanto ser racional, parecia ser a solução da totalidade dos problemas jurisdicionais.

Essa tentativa de mudança/quebra de paradigma é responsável por transferir a “produção do sentido do objetivismo para o subjetivismo; da coisa para a mente/consciência (subjetividade assujeitadora e fundante); da ontologia (metafísica clássica) para a filosofia da consciência (metafísica moderna)", como bem define Streck (2009, p. 68). Com guarida nesse panorama, é possível constatar que o sujeito inserido no paradigma da filosofia da consciência acaba por, sob o ponto de vista de Alves e Oliveira (2017, p. 139-40), “criar seu objeto num processo de objetivação do mundo, ao passo que a mediação da subjetividade torna-se condição de possibilidade do próprio conhecimento."

Dito de outro modo, a subjetividade é responsável por inaugurar uma "pretensão de se demarcar a objetividade plena do conhecimento jurídico por meio do sujeito racional: aquele considerado como um fim em si mesmo e, portanto, em oposição aos objetos" (TRAESEL, 2011, p. 145). Alicerçado nessas ideias absolutamente antropocêntricas, típicas das crescentes matrizes iluministas que ascendiam às diversas esferas da sociedade, é que o paradigma da filosofia da consciência acabou "atribuindo à razão humana toda a origem do conhecimento" (ISAIA, 2017, p. 221).

Para Obaldia e Gasparetto (2019), diante de todas as características ora apresentadas, é possível afirmar que a filosofia da consciência - com seu consequente deságue em posturas eivadas de subjetividade - é insuficiente enquanto paradigma filosófico, mormente no que diz respeito à esfera do direito e, pois, das decisões judiciais. A discricionariedade judicial, advinda da implementação do ideal de subjetividade que é típico dessa linhagem filosófica, "entrega ao sujeito a possibilidade de manejar o objeto (direito) da forma como lhe aprouver (baseado em seu conhecimento e suas convicções)" (OBALDIA; GASPARETTO, 2019, p. 19875).

Significa dizer que, quando da inserção do direito processual civil no paradigma filosófico de subjetividade, a consciência do julgador - enquanto atributo de sua razão adquire o brilhantismo de decidir como quiser. Sob essa ótica, as práticas judiciais discricionárias passam a ser justificadas por seus defensores com vistas à ideia de que a discricionariedade seria o "espaço ocupado pela razão prática nos casos de insuficiência da plenitude da razão teórica." (STRECK, 2017, p. 26) 
Seja tanto no paradigma da objetividade quanto no paradigma da subjetividade, em sua roupagem clássica ou moderna, a metafísica sempre esteve presente nas bases de pensamento que fomentaram a construção de tais pensamentos. Afastá-la é condição de possibilidade para a tentativa de quebra das matrizes objetivistas e subjetivistas que foram construídas ao longo do tempo. No propósito de romper com tais ideais, emerge uma nova matriz filosófica aplicada ao direito. Conforme salienta Isaia (2011, p. 91), “o maior golpe à metafísica seria oriundo da mudança do paradigma da filosofia da consciência para a filosofia da linguagem. Somente a partir de então é possível falar na linguagem como abertura, como acesso ao mundo."

Ainda que, segundo as ideias de Isaia (2017), o possível rompimento com a filosofia da consciência pela viragem linguística - na perspectiva ontológico-continental -, a fim de tenha ocorrido em meados do século XX, a mudança de paradigma é complexa difícil de ser concretizada em termos práticos. A (tentativa de) invasão na filosofia pela linguagem, através do giro ontológico-linguístico, não foi capaz de erradicar a subjetividade do/no terreno do direito processual. É que "a mudança de paradigma (da filosofia da consciência para a filosofia da linguagem) não teve a devida recepção no campo da filosofia jurídica e da hermenêutica no cotidiano das práticas judiciárias e doutrinárias brasileiras.” (STRECK, 2014, p. 57)

Em virtude disso, Isaia (2017, p. 205) é preciso ao alertar sobre o fato de ser "possível concluir que a processualística civil ainda é refém do pensamento liberalindividualista-normativista e da filosofia da consciência." Sua inserção na jurisdição, notadamente no que diz respeito aos conteúdos decisórios, acontece amiúde. Significa dizer que, para uma parcela considerável de julgadores, julgar e fundamentar decisões com fulcro nas suas ideias, experiências e motivações pessoais ainda parece ser um ato revestido de completa legitimidade.

Consoante ao entendimento de Streck (2017), as decisões judiciais (até hoje) bebem inegavelmente da fonte do subjetivismo, produzida pelo paradigma da filosofia da consciência, fazendo com que venha à tona tão somente um eu que comanda o mundo; alegando, ainda que indiretamente, que o mundo é controlado pelo sujeito, consciente ou inconscientemente. Sob esse aspecto, é também Streck (2013, p. 38) quem alerta sobre o fato de que "quando o interprete decide como lhe convém, já não há direito; há, apenas, o direito dito pelo intérprete." 
A relação estabelecida entre o paradigma da subjetividade e a tomada de decisões judiciais com base no livre convencimento do juiz (ainda que seja adjetivado como motivado) é explícita. Se, no CPC/73, o art. 131 previa tal possibilidade de suprir o dever constitucional de fundamentação das decisões, previsto no art. 93, IX da Constituição Federal de 1988, essa previsão ficou (ou deveria ter ficado) no passado do processo. O CPC/15 nada dispõe acerca da livre convencimento. Tal instituto não tem amparo legal em nenhum ponto da redação da atual codificação processual civil nem mesmo no art. 371 (que corresponde ao dispositivo supracitado do código revogado). Assim, é possível compreender que não mais pode ser invocado como fonte de fundamentação das decisões judiciais.

A interligação entre a filosofia da consciência e o livre convencimento é, sem dúvidas, estreita. $\mathrm{O}$ ato de o juiz fundamentar uma decisão com fulcro no seu convencimento livre não pode estar mais adstrito à sua consciência - enquanto (erroneamente entendida como) morada do conhecimento - do que se mostra já em primeira vista. A discricionariedade, fruto de tal paradigma, vai "abrindo espaço para várias respostas e a consequente livre escolha do juiz", conforme alega Streck (2009, p. 76). Ao encontro de tal ideia, há que

\footnotetext{
Quando alguém diz que o julgador possui livre convencimento, está a se referir que é a sua consciência-de-si-do-pensamento-pensante que deverá determinar o resultado da apreciação da prova. Só essa constatação já é significativa o bastante para se demonstrar que, se uma única consciência pode formar uma convicção sobre aquilo que foi trazido ao processo, não há aqui democracia. E não há, igualmente, aquilo que define a magistratura, que é a efetiva imparcialidade. Pelo contrário, há uma assunção voluntária que acaba por transferir ao juiz a condição de legibus solutus para aquele caso concreto que por ele deve ser julgado. (STRECK; OLIVEIRA, 2017)
}

É dizer que, em se tratando de livre convencimento - e, por óbvio, do paradigma da filosofia da consciência -, na perspectiva de Streck e Oliveira (2017), é possível notar que tanto a sua construção quanto a sua estruturação aparecem no contexto da construção do imaginário moderno, local em que o sujeito (homem dotado de razão) busca se ratificar como o próprio construtor dos significados e produtor das ideias. Isso faz com que, inegavelmente, a jurisdição processual seja (um dos) reflexo(s) do arraigamento das matrizes subjetivistas que persistem aos tempos atuais. 


\section{O ART. 371 É BARREIRA CONTRA A DISCRICIONARIEDADE?: COMO FICAM AS (TENTATIVAS DE) FUNDAMENTAÇÃO DAS DECISÕES JUDICIAIS COM BASE NO LIVRE CONVENCIMENTO DO JULGADOR PÓS CPC/15}

Ao longo do primeiro capítulo, a pesquisa foi centrada na necessária discussão acerca da presença da subjetividade, fruto do arraigamento do paradigma da filosofia da consciência na jurisdição processual, no âmbito das decisões judiciais e também na sua interligação com o instituto do livre convencimento do juiz. Destarte, no sentido de dar seguimento à linha de raciocínio construída até então pela presente pesquisa, a segunda seção deter-se-á a investigar as (tentativas de) fundamentações das decisões judiciais embasadas no livre convencimento do julgador em um cenário jurídico regido pelo $\mathrm{CPC} / 15$, onde tal instituto não encontra mais guarida legal.

A obrigatoriedade de fundamentação das decisões judiciais é, atualmente, um dever para o juiz; e um direito para as partes - constitucionalmente consagrado. A Constituição da República Federativa do Brasil de 1988 (CF/88), em seu art. 93, inciso IX, traz a previsão de que "todos os julgamentos dos órgãos do Poder Judiciário serão públicos, e fundamentadas todas as decisões, sob pena de nulidade [...]" (BRASIL, 1988). De modo a alinhar-se com a perspectiva constitucional vigente, em idêntica forma, o CPC/15 tratou de ratificar essa previsão em seu art. 11, caput, consolidando o ideal de construção de um processo, de fato, democrático (e, por isso, constitucional).

Ao tratar do $\mathrm{CPC} / 15$, é necessário salientar outro dispositivo inovador que tem, no seu conteúdo, uma disposição muito importante; trata-se da superação (ao menos, formal) do livre convencimento do magistrado como forma de suprir o já mencionado dever de fundamentação das decisões em direito. Para Uadi Bulos (2000, p. 185), o livre convencimento pode ser entendido como "a técnica mediante a qual as provas são examinadas de acordo com a consciência judicial, à luz das impressões colhidas no processo [...]". Em face de tal conceituação, a relação entre o instituto do livre convencimento e a filosofia da consciência salta, outra vez, às vistas.

A proximidade entre ambos pode ser ratificada com fulcro nas palavras de Streck (2010, p. 26), ao dispor que o livre convencimento dos juízes é "a técnica mediante a qual as provas são examinadas de acordo com a consciência judicial, à luz das impressões colhidas no processo.” Em ambas doutrinas é perceptível a consciência do magistrado sempre presente na 
fundamentação com base no livre convencimento. É como se recorrer à própria consciência fosse a conditio sine qua non da utilização do livre convencimento judicial no corpo de uma decisão.

De posse disso e em um ato comparativo entre o código passado (CPC/73) e o vigente (CPC/15), o dispositivo considerado reflexo do art. 131 do $\mathrm{CPC} / 73$, que previa a fundamentação das decisões com base no livre convencimento do julgador, é o art. 371 no CPC/15. Tal artigo é responsável por trazer a previsão de que, literalmente, “o juiz apreciará a prova constante dos autos, independentemente do sujeito que a tiver promovido, e indicará na decisão as razões da formação de seu convencimento.” (BRASIL, 2015). Sob tal ótica, é nítida no texto legal a impossibilidade do livre convencimento motivado fundamentar validamente a decisão judicial.

Assim, desde o início da vigência do CPC/15, mais precisamente no mês de março do ano de 2016, a leitura do art. 371, com base em uma compreensão hermenêutica, permite afastar todo e qualquer ato decisório fundado no livre conhecimento - motivado ou não. Ocorre que, como já fora citado na seção anterior, mesmo com a abolição da previsão legal, determinadas práticas decisórias na aplicação do direito insistem em revisitar ideais do passado que, tanto hermeneuticamente quando textualmente, não encontram mais guarida no ordenamento.

Nesse sentido, imprescindível tratar, como um primeiro exemplo, a decisão proferida pelo Superior Tribunal de Justiça (STJ), no ano de 2019 (e, pois, já há mais de três anos de vigência do $\mathrm{CPC} / 15$ ) que reflete exatamente o apego ao texto suprimido do CPC/15. Segue a ementa do Agravo Interno em Agravo em Recurso Especial no 1.784.052/CE, de relatoria do Ministro Antonio Carlos Ferreira:

PROCESSUAL CIVIL. AGRAVO INTERNO NO AGRAVO EM RECURSO ESPECIAL. AÇÃO DE INDENIZAÇÃO. AMPLIAÇÃO DE REDE ELÉTRICA. CERCEAMENTO DE DEFESA. AUSÊNCIA DE ANÁLISE DE TODAS AS PROVAS DOS AUTOS. INEXISTÊNCIA. LIVRE CONVICÇÃO. REEXAME DE CONTRATO E CONTEÚDO FÁTICO-PROBATÓRIO. SÚMULAS 5 E 7 DO STJ. DECISÃO MANTIDA.

1. "O CPC/2015 manteve em sua sistemática o princípio da persuasão racional ou do livre convencimento motivado, adotado pela norma adjetiva revogada (arts. 130 e 131 do CPC/1973), conforme o disposto nos seus arts. 370 e 371 , segundo os quais compete ao juiz a direção da instrução probatória, apreciando livremente as provas produzidas nos autos, a fim de formar a sua convicção acerca da controvérsia submetida a sua apreciação, desde que devidamente fundamentada, não havendo que se falar na violação desses dispositivos legais quando o juiz, sopesando todo o conjunto probatório produzido e carreado ao feito, julga a causa 
em sentido oposto ao pretendido pela parte, como no caso dos autos" (AgInt no REsp n. 1.784.052/CE, Rel. Ministro Marco Aurélio Bellizze, Terceira Turma, julgado em 17/6/2019, DJe 25/6/2019).

2. [...]

(AgInt no AREsp 1263615/MS, Rel. Ministro Antonio Carlos Ferreira, Quarta Turma, julgado em 24/09/2019, publicado no DJe em 30/09/2019) (grifo nosso) (BRASIL, 2019).

A ementa supracitada não é caso isolado. Uma simples pesquisa jurisprudencial com o termo "livre convencimento", no sítio eletrônico do STJ, é capaz de demonstrar o apego dos ministros ao livre convencimento, mesmo em face do CPC/15 (que, repise-se, nada dispõe sobre o instituto). A decisão, aqui, é proferida em sede de Agravo Interno em Agravo em Recurso Especial nº 863.214/MA, de relatoria do Ministro Napoleão Nunes Maia Filho. Eis, pois, a colação de mais uma ementa; essa, do corrente ano de 2020:

PROCESSUAL CIVIL E TRIBUTÁRIO. AGRAVO INTERNO NO AGRAVO EM RECURSO ESPECIAL. ALEGAÇÃO DE CERCEAMENTO DE DEFESA, ANTE A NECESSIDADE DE AMPLA PRODUÇÃO DE PROVAS. ART. 130 DO CPC/1973. PRINCÍPIO DO LIVRE CONVENCIMENTO MOTIVADO. ACÓRDÃO EM CONSONÂNCIA COM A ORIENTAÇÃO DESTA CORTE. SUMULA 83/STJ. AVALIAÇÃO DA NECESSIDADE DAS PROVAS. IMPOSSIBILIDADE EM RESP. AGRAVO INTERNO DA CONTRIBUINTE A QUE SE NEGA PROVIMENTO.

1. No âmbito judicial vige o princípio do livre convencimento motivado do Juiz (art. 131 do CPC/1973, atual art. 371 do Código Fux), e não o sistema de tarifação legal de provas. Assim, se o Magistrado, analisando as provas dos autos, entender não haver necessidade de produzir as provas indicadas pelas partes, sobretudo quando ausente justificativa da utilidade do meio de prova pretendido, não há que se falar em cerceamento de defesa.

2. [...]

(AgInt no AREsp no 863.214/MA, Rel. Ministro Napoleão Nunes Maia Filho, Primeira Turma, julgado em 30/03/2020, publicado no DJe em /04/2020). (grifos nossos) (BRASIL, 2020)

Em ambas as decisões o aprisionamento do julgador ao CPC/73 é visível, mormente no que tange à redação do antigo art. 131, que autorizava a fundamentação das decisões judiciais com fulcro no livre convencimento motivado. Afirmando, equivocadamente, que o CPC/15 ainda prevê tal possibilidade, o acórdão tenta perpetuar a ideia de subjetividade do julgador. Frise-se, aqui, que a pesquisa cuidou de trazer ao trabalho duas ementas de diferentes relatorias, justamente com a finalidade de demonstrar que o apego à fundamentação do livre convencimento (por si só ou motivado) está presente no entendimento de mais de um ministro que integra o STJ. 
A equivocada compreensão de que a alegação do livre convencimento do juiz basta para suprir o dever de fundamentar da decisão judicial é (uma das) face(s) que comprova a (ainda) permanente presença da filosofia da consciência no ambiente processual, que acredita que o fundamento decisório encontra-se na consciência do julgador. Ao ler os acórdãos supracitados, que é apenas um demonstrativo das incontáveis decisões que reproduzem essa espécie de pensamento, como já fora dito, é possível perceber na prática forense a abertura à discricionariedade. Nesse sentido, Isaia (2011, p. 98) confessa que "impressiona como esse protagonismo judicial, o que não é de todo enfrentado pela literatura processual civil, mantém-se arraigado à filosofia da subjetividade, à metafísica ocidental e sua aposta no subjetivismo do sujeito."

Em face de uma compreensão hermenêutica das decisões judiciais, a conduta de negação da supressão do livre convencimento do ordenamento processual civil vigente é preocupante. Também sob o espectro de Isaia (2011, p. 97), os julgadores, agindo assim, demonstram estar visivelmente "arraigados ao procedimento para legitimar sua íntima convicção em relação a determinado caso submetido a "sua" jurisdição." É o demonstrativo do apego à subjetividade na esfera decisória da jurisdição processual.

\footnotetext{
A sentença (ou acordão), afinal, é produto de um sentimento pessoal, de um subjetivismo ou deve ser o resultado de uma análise do direito e do fato (sem que se cinda esses dois fenômenos) de uma linguagem pública e com rigorosos critérios republicanos? Porque a democracia é o respeito às regras do jogo. (STRECK; OLIVEIRA, 2017)
}

As condutas judiciais protagonistas, que autorizam discricionariedades no ato de julgar, não acusam compatibilidade com nossa atual configuração de Estado e, por isso, também de jurisdição processual, ambos compreendidos mormente sob seu aspecto democrático. "São as partes processuais que orientam a fundamentação da decisão (relação jurídica entre normas), e não mais uma vontade emanada da esfera solitária de convicção do juiz.” (DEL NEGRI, 2011, p. 87) Indo ao encontro dessa ideia, Isaia (2017, p. 175) também aborda que "a aposta no solipsismo judicial, na subjetividade do juiz, na fixação de parte da doutrina em atribuir à magistratura uma posição sobrelevada [...] não é compatível com o Estado Democrático de Direito.”

Em virtude de todo o exposto, ancorado em face de um modelo jurisdicional democrático e constituído na linguagem e pela linguagem, o cenário do direito processual 
civil no país precisa quebrar com esse paradigma o quanto antes. Sabendo disso, é imperioso salientar que

\begin{abstract}
Precisamos investir nas condições de possibilidade de um modelo diverso de Direito, apto a superar esse convívio pacífico com o protagonismo judicial, aqui compreendido como a possibilidade de o juiz - a quem todos os conflitos chegam -, decidir [...] de acordo com a sua moralidade individual, com o seu "prudente arbítrio" ou, enfim, de acordo com todos os nomes a que se dê à sua capacidade de discernimento. (MOTTA, 2012, p. 33)
\end{abstract}

Sob o prisma do pensamento de Streck (2017), a necessidade de discutir as discricionariedades judiciais é, sobretudo, uma questão de democracia e pela democracia. Por isso, as críticas formuladas às decisões eivadas de subjetividade não podem ser concebidas como uma ideia de proibição de interpretação. O que se busca expor, quando das críticas ao paradigma da filosofia da consciência, é que "a realização/concretização desses textos [...] não depende de - e não pode depender - de uma subjetividade assujeitadora, como se os sentidos a serem atribuídos fossem fruto da vontade do intérprete" (STRECK, 2017, p. 87).

Em face da perspectiva atual de jurisdição processual, é imprescindível salientar que "a atividade interpretativa no Estado Democrático de Direito exige que se supere a figura do juiz solipsista, o qual decide em acordo com sua "vontade", "íntima convicção" etc." (ISAIA, 2011, p. 115). Tanto é assim, que a sua superação (ainda não concretizada) pode ser considerada uma vitória democrática. Fundamentar com fulcro na consciência é prática absolutamente incompatível com o cenário democrático atual em que o Estado está inserido e, pois, não pode mais ser suportado.

As práticas decisionistas, eivadas de subjetividade, não mais podem encontrar refúgio na jurisdição processual. Discutir as decisões judiciais é inegavelmente urgente. Diante da necessidade de se (re)pensar as respostas judiciais, suas matrizes basilares e os elementos que as permeiam, é imprescindível frisar que

Essa resposta (decisão) não pode - sob pena de ferimento do "princípio democrático" - depender da consciência do juiz, do livre convencimento, da busca da "verdade real", para falar apenas nesses artifícios que escondem a subjetividade assujeitadora do julgador (ou do intérprete em geral). (STRECK, 2017, p. 97)

Abandonar as matrizes que compõem o paradigma da filosofia da consciência, no campo das decisões judiciais, é medida urgente que se impõe. Tal afirmação pode ser 
justificada pela argumentação de Streck (2014, p. 38), que é absolutamente preciso ao alertar que "o direito não pode (mais) ser visto como sendo tão somente uma racionalidade instrumental." É intolerável a (persistência da) ideia de que o conhecimento reside na consciência do julgador. O pensamento metafísico moderno que sustenta a subjetividade do julgador enquanto elemento presente nas decisões proferidas no âmbito da jurisdição processual precisa ser abandonado.

Afastar definitivamente a subjetividade, traduzida em discricionariedades ainda presentes em atos decisórios, é uma condição de possibilidade para que a jurisdição processual seja, efetivamente, democrática. Por fim, embasado nesse ponto de vista, sendo a realidade processual construída com sustentáculo da/na linguagem (enquanto elemento que constitui o saber e, pois, a própria compreensão), é que o direito processual civil estará alinhado com os ideais propostos em um Estado Democrático de Direito.

\section{CONCLUSÕES}

Ao final das pesquisas, o presente trabalho permitiu depreender que o cenário jurídico do país vive em constante mutação, com o escopo de acompanhar as demandas provenientes das complexas configurações da sociedade que são desenhadas ao longo da história e, por isso, experimentadas pelo direito. Com isso, há que se ter em mente que as codificações não são estanques e que, principalmente, a jurisdição processual também não é. Nesse aspecto, imprescindível conceber que a realidade jurídica que vige hoje tende a ser alterada através do tempo, com a extinção, inclusão e/ou alteração de instrumentos operacionais.

De tal forma aconteceu com o princípio do livre convencimento (motivado) do magistrado, consagrado pelo CPC/73 no conteúdo do art. 131, que foi suprimido pelo texto do CPC/15. Entendido como uma exclusão hermenêutica, de forma a (tentar) barrar a discricionariedade judicial no ato de julgar, não mais encontra guarida legal desde a vigência do CPC/15, no início do ano de 2016. Ocorre que, ainda que o CPC/15 tenha retirado o livre convencimento motivado como autêntica forma de atender ao dever constitucional de fundamentação das decisões judiciais, ainda é possível verificar decisões em que os julgadores invocam tal princípio com intuito de satisfazer a obrigatoriedade prevista no art. 93, IX da CF/88. 
Com a intenção de ratificar tal fala, as jurisprudências do STJ trabalhadas ao longo de pesquisa foram capazes de demonstrar o problema na prática: nos anos de 2019 e 2020 , os ministros (ainda) dispõem ementas invocando o livre convencimento em suas decisões chegando, inclusive, a afirmarem que a sua previsão legal segue disposta no texto do art. 371 do CPC/15. Destarte, é possível depreender que tais condutas advêm da imersão em uma condição de aprisionamento da mente dos julgadores ao paradigma da filosofia da consciência, que tem como característica principal a discricionariedade (advinda da subjetividade) no ato de julgar.

Afirmar que a fundamentação da decisão judicial que proferiu é o próprio convencimento, livre de limitações de toda sorte, é ratificar que incorpora a ideia de uma metafísica subjetiva (ou moderna, como também é tratada) e, também, que defende o ideal de julgamentos baseados na consciência do julgador, onde se pode levar em conta suas experiências e preferências sociais, em clara dissociação dos propósitos estabelecidos por um Estado Democrático de Direito.

Por fim, ante a todo exposto e de modo a responder a problemática levantada no início do desenvolvimento do trabalho, é possível concluir que o paradigma da filosofia da consciência e sua subjetividade característica (ainda) permeiam as decisões judiciais em uma medida considerável quando comparada ao cenário atual da jurisdição principalmente no que diz respeito à linguagem. Ademais, a relação estabelecida entre a (tentativa de) fundamentação judicial pelo livre convencimento do juiz com o paradigma da filosofia da consciência é absolutamente estreita, de tal modo que é possível afirmar, inclusive, que uma alimenta a outra de maneira simbiótica.

\section{REFERÊNCIAS BIBLIOGRÁFICAS}

ALVES, Fernando de Brito; OLIVEIRA, Guilherme da Fonseca. Entre o esquema sujeitoobjeto e o esquema sujeito-sujeito: considerações sobre um novo paradigma. Revista de Estudos Constitucionais, Hermenêutica e Teoria do Direito (RECHTD). São Leopoldo, v. 9, n. 2, p. 136-150, Mai/Ago 2017. Disponível em: http://revistas.unisinos.br/index.php/ RECHTD/article/ view/rechtd.2017.92.05/6276. Acesso em: 20 fev. 2020.

BRASIL. Código de Processo Civil - Lei no 13.105/2015. Disponível em: http://www. planalto.gov.br/ccivil_03/_ato2015-2018/2015/lei/113105.html. Acesso em 13 mar. 2020. 
BRASIL. Constituição da República Federativa do Brasil de 1988. Disponível em: http://www.planalto.gov.br/ccivil_03/constituicao/constituicao. html. Acesso em: 17 mar. 2020.

BRASIL. Superior Tribunal de Justiça. AgInt no AREsp 863.214/MA. Relator Ministro Napoleão Nunes Maia Filho, Primeira Turma, julgado em 30/03/2020, DJe em 07/04/2020. Disponível em: https://ww2.stj.jus.br/processo/revista/inteiroteor/?Num_registro=2016 00319525\&dt_publicacao=07/04/2020. Acesso em 16 abr. 2020.

BRASIL. Superior Tribunal de Justiça. AgInt no AREsp 1.263.615/MS. Relator Ministro Antonio Carlos Ferreira, Quarta Turma, julgado em 24/09/2019, DJe em 30/09/2019. Disponível em: https://ww2.stj.jus.br/processo/revista/inteiroteor/?numregistro=201800605 634\& dt_publicacao=30/09/2019. Acesso em: 13 mar. 2020.

BULOS, Uadi Lammêgo. O Livre Convencimento do Juiz e as Garantias Constitucionais do Processo Penal. Revista da EMERJ, v. 3, n. 12, 2000, p. 184- 198. Disponível em: https:// www.emerj.tjrj.jus.br/revistaemerj_online/edicoes/revista12/revista12_184.pdf. Acesso em: 20 mar. 2020.

DEL NEGRI, André. Processo Constitucional e Decisão Interna Corporis. Belo Horizonte: Fórum, 2011.

ISAIA, Cristiano Becker. Processo Civil, Atuação Judicial e Hermenêutica Filosófica. Curitiba: Juruá, 2011.

ISAIA, Cristiano Becker. Processo Civil e Hermenêutica: os fundamentos do novo CPC e a necessidade de se falar em uma filosofia no processo. Curitiba: Juruá, 2017.

MOTTA, José Francisco Borges. Levando o direito a sério: uma crítica hermenêutica ao protagonismo judicial. 2. ed. rev. e ampl. - Porto Alegre: Livraria do Advogado, 2012.

OBALDIA, Bruna Andrade; GASPARETTO, Hígor Lameira. O giro linguístico como elemento de uma nova constituição de sentido na jurisdição processual: a superação da filosofia da consciência pela linguagem enquanto condição de possibilidade da relação entre sujeito e objeto. Brazilian Journal of Development. Curitiba, v.5, n. 10 p. 19870-19885, Out. 2019. Disponível em: http://www.brjd.com.br/index.php/BRJD/ article/view/3852/3641. Acesso em 13 mar. 2020.

STRECK, Lenio Luiz; OLIVEIRA, Rafael Tomaz de. Como exorcizar os fantasmas do livre convencimento e da verdade real. Conjur, 2017. Disponível em: https://www.conjur. com.br/2017-jun-24/diario-classe-exorcizar-fantasmas-livre-convencimento-verdade-real. Acesso em: 12 mar. 2020.

STRECK, Lenio Luiz. Compreender o direito: desvelando as obviedades do discurso jurídico. São Paulo: Editora Revista dos Tribunais, 2013.

STRECK, Lenio Luiz. Hermenêutica, Constituição e autonomia do Direito. Revista de Estudos Constitucionais, Hermenêutica e Teoria do Direito (RECHTD), 2009. São 
Leopoldo, v. 1, n. 1, p. 65-77, Jan/Jun 2009. Disponível em: http://revistas.unisinos.br/ index.php/RECHTD/article/view/5137. Acesso em: 17 mar. 2020.

STRECK, Lenio Luiz. Hermenêutica jurídica e(m) crise: uma exploração hermenêutica da construção do Direito. 11. ed. Porto Alegre: Livraria do Advogado Editora, 2014.

STRECK, Lenio Luiz. O que é isto - Decido conforme minha consciência? 6. ed. Porto Alegre: Livraria do Advogado, 2017.

STRECK, Lenio Luiz. O que é isto - Decido conforme minha consciência? Porto Alegre: Livraria do Advogado, 2010.

TRAESEL, Clório Erasmo. Filosofia e direito: a filosofia da consciência e o fenômeno jurídico. Tese, Doutorado em Direito, Programa de Pós-Graduação em Direito, Universidade do Vale do Rio dos Sinos, São Leopoldo, 2011. Disponível em: http://www.repositorio. jesuita.org.br/handle/UNISINOS/4799. Acesso em: 18 mar. 2020. 